\title{
Enhance the Productivity of Cumin in Barmer District of Rajasthan, India
}

\author{
P. Pagaria, H. D. Choudhary* and L. R. Choudhary \\ Krishi Vigyan Kendra, Gudamalani - Barmer (Rajasthan), India \\ *Corresponding author
}

\section{Keywords}

Cumin, Spices,

Productivity, Front

line Demonstration etc.

\section{Article Info}

Accepted:

15 December 2019

Available Online:

20 January 2020

\section{A B S T R A C T}

Krishi Vigyan Kendra conducted front line demonstration on Cumin variety GC-04 at farmer's fields in district Barmer during years 2012-13 to 201819. The productivity and economic returns of Moong in demonstrated plots were calculated and compared with the corresponding local check. The data obtained was pooled for seven years. It was observed that on an average 27.14 percent higher grain yield was recorded in demonstration plots than the local check. The extension gap, technology gap and technology index were $1.37 \mathrm{q} / \mathrm{ha}, 5.09 \mathrm{q} / \mathrm{ha}$ and 42.47 percent, respectively. An additional investment of Rs.2520/ha coupled with scientific monitoring of demonstration and non monetary factors resulted in additional return of Rs. 22696/ha over the farmers practices. Fluctuating minimum selling price of Cumin during different years influenced the economic returns per unit area.

\section{Introduction}

Front line demonstration was conducted on Cumin by Krishi Vigyan Kendra. The main objectives of the study were to exhibit the performance of recommended high yielding Cumin varities with recommended practices for harvesting higher crop yields. To compare the yield levels of local check (farmers practices) and FLD plots. To collect feedback for further improvement in the performance of Cumin cultivation practices.
Botanical name of Cumin is Cuminum cyminum. In India, it is known as 'Jeera' or 'Zeera' in Hindi. It is an important spice used in Indian kitchens for flavoring various food preparations. The flavor of cumin seeds is due to the presence of a volatile oil. In indigenous varieties of cumin, this volatile oil is present up to $2.5-3.5 \%$. Cumin seeds are extensively used in various ayurvedic medicines also especially for the conditions like obesity, stomach pain and dyspesia. Nutritional value of cumin seeds is as follows: $17.7 \%$ protein, $23.8 \%$ fat, $35.5 \%$ carbohydrate and $7.7 \%$ minerals. Cumin are dried seeds, is used to 
enhance the flavor of foods. Like any other agricultural product, Cumin may be contaminated by pathogens, naturally occurring toxins such as mycotoxins, agrochemicals such as fertilizers and pesticides, heavy metals and accidental contaminants. Food safety is of considerable significance in this globalized era and the safety of Cumin depends on maintaining good agricultural and hygienic practices along the food chain during primary production, postharvest, packing, processing, retail and at the point of consumption.

\section{Importance of GAP}

Good Agricultural Practices or GAP is "practices that need to be applied on farms to ensure food safety during pre-production, production, harvest and post-harvest. In many cases such practices also help protect the environment and safety of workers." They are a collection of principles to apply to farm production and post-production processes, taking into account economic, social and environmental sustainability. The purpose of this guide varies from fulfillment of trade and government regulatory requirements, in particular with regard to food safety and quality, to more specific requirements such as practices to be adopted during post harvest operations.

\section{Materials and Methods}

The front line demonstrations on moong were conducted at farmer's field in district Barmer to assess its performance during the year 2012-2013 to 2018-19. The soil of the district is generally sandy to sandy loam in texture which is low organic carbon (0.09- $0.215 \%)$, available phosphorus (11-14 $\mathrm{kg} / \mathrm{ha})$ and medium to high in potash. Each demonstration was of 0.4 ha area and the critical inputs were applied as per the package of practices. The quality seed of Cumin variety during all the years of the study was used for conducting FLD. The sowing was done during November and harvested during March to April. Demonstrated at farmers' fields were regularly monitored by scientist of Krishi Vigyan Kendra from sowing to harvesting. The grain yield of demonstration crop was recorded and analyzed. Different parameters were calculated to find out technology gaps (Yadav et al., 2004) as follows

Extension gap $=$ Demonstration yield - Local check yield

Technology gap = Potential yield Demonstration yield

Technology index = Potential yield Demonstration yield $\mathrm{x}$ 100/Potential Yield

\section{Results and Discussion}

\section{Grain yield}

On an average the demonstrated plots showed 27.14 per cent increase in seed yield (Table 2).

The highest increase in seed yield $(53.01 \%)$ was observed in year 2018-19 it which might be due to seed of improved and other improved variety technologies about which the farmers were ignorant.

\section{Extension gap}

An extension gap between demonstrated technology and farmers practices range from 0.9 to $2.2 \mathrm{q} / \mathrm{ha}$ during different seven years and on average basis the extension gap was $1.37 \mathrm{q} /$ ha (Table 2). This gap might be attributed to adoption of improved technology in demonstrations which resulted in higher grain yield than the traditional farmer's practices. 


\section{Technology gap}

Wide technology gap were observed during different years and this was lowest $(4.7 \mathrm{q} / \mathrm{ha})$ during 2013-14 and was highest during (5.68 q/ha) during 2017-18. The average technology gap returns found was 5.09 q/ha. The difference in technology gap during different years could be due to more feasibility of recommended technologies during different years. Similarly, the technology index for all the demonstrated during different years were in accordance with technology gap. Higher technology for transferring to farmers and insufficient extension services for transfer of technology.

\section{Economic gap}

Different variables like seed, fertilizers, bio fertilizers and pesticides were considered as critical inputs for the demonstration as well as farmers practices and on an average an additional investment of Rs. 22696.50/ha were made under demonstrations. The highest incremental benefit: cost ratio was 4.25 during the year 2017-18. Overall average BCR was found to be 2.90. The results confirm the findings of frontline demonstrations on oilseed and pulses crops by Yadav et al., (2004) and Lathwal (2010).

In conclusion, frontline demonstration programme was effective in changing attitude of farmers towards Cumin cultivation. Cultivation of demonstrated plots of Cumin with improved technologies has increased the skill and knowledge of the farmers. FLD also helped in replacement of local un recommended varieties with improved recommended varieties. This also improved the relationship between farmers and scientist and built confidence between them. The farmers where improved technology was demonstrated also acted as primary source of information for other farmers on the improved practices of Cumin cultivation and also acted as source of good quality pure seeds in their locality for the next crop. The concept of Front line demonstration may be applied to all farmer categories including progressive farmers for speedy and wider dissemination of the recommended practices to other members of the farming community.

Table.1 Difference between demonstration package and farmers practices of Cumin

\begin{tabular}{|c|c|c|c|}
\hline $\begin{array}{l}\text { S. } \\
\text { No. }\end{array}$ & $\begin{array}{l}\text { Particular } \\
\text { practices }\end{array}$ & Demonstration package & Farmers practices \\
\hline 1 & Variety & GC 04 & Local \\
\hline 2 & Seed rate & $12 \mathrm{~kg} / \mathrm{ha}$ & $15-20 \mathrm{~kg} / \mathrm{ha}$ \\
\hline 3 & Seed treatment & $\begin{array}{l}\text { Carbendazim@2gm/kg seed + } \\
\text { Trichoderma@4g/kg seed }\end{array}$ & Not applied \\
\hline 4 & Sowing method & Line/Broadcasting & Broadcasting \\
\hline & Sowing time & 15-30 Nov. & 15 Oct-10 Dec \\
\hline 5 & $\begin{array}{l}\text { Fertilizers' } \\
\text { doses }\end{array}$ & $\begin{array}{l}\text { Recommended dose }\{30: 20: 10 \\
(\mathrm{N}: \mathrm{P}: \mathrm{K})\}\end{array}$ & $\begin{array}{l}\text { without } \\
\text { recommendation }\{50: 50: 00 \\
(\mathrm{N}: \mathrm{P}: \mathrm{K})\}\end{array}$ \\
\hline 6 & $\begin{array}{l}\text { Plant protection } \\
\text { measures }\end{array}$ & $\begin{array}{lcl}\text { Need based spray } & \text { of } \\
\text { insecticides and fungicides } & \\
\text { (Carbendazim } 50 & \text { wp, } \\
\text { Dimethoate, Zineb 68\%) } & \end{array}$ & $\begin{array}{l}\text { Higher dose of insecticides and } \\
\text { pesticides } \\
\text { (Use Imidachloprid in } 20 \mathrm{ml} \text { in } 15 \\
\text { lit water) }\end{array}$ \\
\hline
\end{tabular}


Table.2 Grain yield and gap analysis of front line demonstration on Cumin at farmer's field

\begin{tabular}{|c|c|c|c|c|c|c|c|c|c|c|}
\hline \multirow[b]{2}{*}{ Year } & \multirow[b]{2}{*}{ Crop } & \multirow[b]{2}{*}{ Variety } & \multirow[b]{2}{*}{$\begin{array}{r}\text { Demo } \\
\text { area } \\
\text { (ha) }\end{array}$} & \multirow[b]{2}{*}{$\begin{array}{c}\text { Farmers } \\
\text { (No.) }\end{array}$} & \multicolumn{5}{|c|}{ Yield (q/ha) } & \multirow{2}{*}{$\begin{array}{l}\text { Technology } \\
\text { index }(\%)\end{array}$} \\
\hline & & & & & Demo & Check & $\begin{array}{c}\text { Increase } \\
(\%)\end{array}$ & $\begin{array}{c}\text { Extension } \\
\text { Gap }\end{array}$ & $\begin{array}{c}\text { Technology } \\
\text { Gap }\end{array}$ & \\
\hline 2012-2013 & Cumin & GC-4 & 10 & 5 & 7.10 & 6.00 & 18.33 & 1.10 & 4.90 & 40.80 \\
\hline 2013-2014 & Cumin & GC-4 & 10 & 5 & 7.30 & 6.00 & 21.67 & 1.30 & 4.70 & 39.10 \\
\hline 2014-2015 & Cumin & GC-4 & 36 & 15 & 7.30 & 6.10 & 19.67 & 1.20 & 4.70 & 39.10 \\
\hline 2015-2016 & Cumin & GC-4 & 30 & 15 & 6.70 & 5.80 & 19.67 & 0.90 & 5.30 & 44.10 \\
\hline 2016-2017 & Cumin & GC-4 & 25 & 10 & 7.25 & 6.00 & 20.84 & 1.25 & 4.75 & 39.50 \\
\hline 2017-2018 & Cumin & GC-4 & 25 & 10 & 6.32 & 4.62 & 36.80 & 1.70 & 5.68 & 47.30 \\
\hline 2018-2019 & Cumin & GC-4 & 35 & 15 & 6.35 & 4.15 & 53.01 & 2.20 & 5.65 & 47.00 \\
\hline
\end{tabular}


Table.3 Economic analysis of demonstrated plots and farmers practice

\begin{tabular}{|c|c|c|c|c|c|c|c|c|}
\hline \multirow[t]{2}{*}{ Year } & \multirow[t]{2}{*}{ Demo } & \multirow[t]{2}{*}{ Check } & \multirow[t]{2}{*}{ Demo } & \multirow[t]{2}{*}{ Check } & \multicolumn{2}{|c|}{$\begin{array}{l}\text { Net returns } \\
\text { (Rs./ha) }\end{array}$} & \multicolumn{2}{|c|}{ BCR } \\
\hline & & & & & Demo & Check & Demo & Check \\
\hline $2012-2013$ & 36000 & 33000 & 98000 & 73000 & 62000 & 40000 & 2.72 & 2.13 \\
\hline 2013-2014 & 38000 & 35000 & 100000 & 75000 & 62000 & 40000 & 2.63 & 2.03 \\
\hline 2014-2015 & 38000 & 35500 & 100000 & 78000 & 62000 & 42500 & 2.63 & 2.19 \\
\hline 2015-2016 & 33500 & 30500 & 87000 & 64200 & 53500 & 33700 & 2.60 & 2.15 \\
\hline 2016-2017 & 33500 & 30500 & 87000 & 64200 & 53500 & 33700 & 2.60 & 2.27 \\
\hline $2017-2018$ & 22300 & 19425 & 94800 & 69300 & 72500 & 49875 & 4.25 & 4.01 \\
\hline 2018-2019 & 33160 & 32414 & 95250 & 62050 & 62090 & 29636 & 2.93 & 2.09 \\
\hline
\end{tabular}

\section{Acknowledgement}

The pride of place in this galaxy belongs to esteemed Incharge of KVK, Dr. P. Pagaria, Senior Scientist \& Head, Krishi Vigyan Kendra, Gudamalani, Barmer-II, Agriculture University, Jodhpur for suggesting and planning the present investigation, engrossing guidance and immense zeal of hard work, constructive criticism, kind and gracious patronage throughout the course of investigation and preparation of manuscript without which this work would not have been the light of the day.

\section{References}

Balai C M, Bairwa R K, Verma L N, Roat B L, and Jalwania R (2013). Economic impact of front line demonstration on cereal crops in Tribal Belt of Rajasthan International Journal of Agricultural Sciences 3 (7): 566-570.

Das P (2007). Proceedings of the meeting of
DDG(AE), ICAR, with officials of state Department, ICAR institutes and Agricultural Universities, NRC Mithun, Jharmapani, Zonal Coordinating Unit, Zone-III, Barapani, Meghlaya, India. Pp6.

Hussain, M.M., Parigrahi, R and Ghosal, M.K. (1995): Extent of adoption constraints to the diffusion of farm and allied technology among farmers of Balipal block. Environment and Ecol, 13(2): 269-274.

Lathwal OP (2010). Evaluation of frontline demonstration on blackgram in irrigated agro ecosystem. Annals of Agricultural Research 31 (1\&2) 24-27.

Paramjit Kaur, Amanpreet Kaur, Balbir Kaur and Kuldeep Singh (2014). Performance of Front line Demonstration on Summer Moong in Jalandhar district. J Krishi Vigyan 2014, 3(1):58-61.

Singh Narahari, Prasad Angad and Ram Daya (2005). Front line Demonstration on Rice Manipur. Agricultural extension 
Review. Pp.6-7.

Yadav D B, Kamboj B K and garg R B (2004). Increasing the productivity and profitability of sunflower through frontline demonstration in irrigated agroecosystem of eastern Haryana. Haryana J. of Agronomy 20 (1\&2): 3335.

\section{How to cite this article:}

Pagaria, P., H. D. Choudhary and Choudhary, L. R. 2020. Enhance the Productivity of Cumin in Barmer District of Rajasthan. Int.J.Curr.Microbiol.App.Sci. 9(01): 2122-2127. doi: https://doi.org/10.20546/ijcmas.2020.901.241 